\title{
APLIKASI LARVA BLACK SOLDIER FLY (Hermatia illucens) SEBAGAI PAKAN ALAMI DAN PAKAN BUATAN (PELET) UNTUK IKAN RAINBOW KURUMOI (Melanotaenia parva)
}

\section{APPLICATION OF BLACK SOLDIER FLY LARVAL (Hermetia illucens) AS FEED AND ARTIFICIAL FEED (PELLETS) FOR RAINBOW KURUMOI FISH (Melanotaenia parva)}

\author{
Muhammad Syahrizal Irfan dan Abdul Manan
}

Fakultas Perikanan dan Kelautan Universitas Airlangga

Kampus C Mulyorejo - Surabaya, 60115 Telp. 031-5911451

\begin{abstract}
Fish flour is raw materials of main protein source for fish feed, however because of its existence day by day gets expensive so that the other alternative feed material needed as the alternate of fish flour that is maggot which is the larva of insects kind of fly which contains crude protein about $42 \%$. This Study was held in Research and Aquaculture Cultivation Center of Ornamental Fish Depok, West Java in January $14^{\text {th }}$ until February $14^{\text {th }} 2013$. The goal of this Study is to know the aplication of black soldier fly larval (Hermetia illucens) as the feed of rainbow kurumoi fish (Melanotaenia parva). Maggot culture was undertaken by mixing PKM and water with the comparison of 1:2 then fermented in fiber basin. Then interspersed with wire and above it there was a dry banana leaf to lay the eggs and covered by wire again, and then eggs harvesting was undertaken which was moved to the egg hatching basin which contain PKM which had been fermented. After 2 weeks maggot was ready to be harvested from the hatching basin. Maggot and maggot pellets could fulfill the need of nutrition for rainbow kurumoi fish, this case could be seen by the existence of weight increase and length increase of the fish.
\end{abstract}

Keywords : rainbow kurumoi fish, black soldier fly larval, apllication and culture maggot

\section{Pendahuluan}

Dalam kegiatan budidaya ikan, pakan memiliki peranan penting dalam peningkatan produksi. Pada budidaya intensif, kultivan bergantung pada pakan buatan yang disuplai oleh pembudidaya. Pakan yang diberikan harus berkualitas tinggi, bergizi dan memenuhi syarat untuk dikonsumsi kultivan yang dibudidayakan, serta tersedia secara terus menerus sehingga tidak mengganggu proses produksi dan dapat memberikan pertumbuhan yang optimal. Pada budidaya intensif, lebih dari $60 \%$ biaya produksi tersedot untuk pengadaan pakan (Kordi, 2009).

Saat ini salah satu sumber protein yang diharapkan dapat menggantikan tepung ikan adalah maggot. Maggot merupakan larva black soldier fly (Hermetia illucens) yang diproduksi secara biokonversi dengan menggunakan substrat dari buangan proses pembuatan minyak kelapa sawit (bungkil kelapa sawit atau Palm Kernel Meal). Maggot mengandung protein sekitar $32.31 \%-60.20 \%$ dan lemak yang tinggi sekitar $9.45 \%-13.30 \%$ tergantung umur dan kualitas substrat (Fahmi dan Subamia, 2007).

Maggot selain sebagai sumber protein alternatif pengganti tepung ikan, juga memiliki fungsi sebagai pakan alternatif untuk ikan yang dapat diberikan dalam bentuk segar (fresh). Hasil ujicoba pemanfaatan maggot yang telah dilakukan pada ikan-ikan seperti arwana, betutu, lele dan gabus sangat menyukai maggot fresh sebagai pakannya (Fahmi et al., 2008).

Ikan pelangi yang umumnya dikenal dengan nama ikan rainbow atau "rainbowfish" merupakan salah satu jenis ikan hias yang sangat populer bagi kalangan pencinta ikan hias akuarium. Ikan ini termasuk dalam famili Melanotaeniidae, dengan tubuh kecil multiwarna dan jika diletakkan dalam akuarium dengan kondisi tertentu, tubuhnya merefleksikan warna-warna pelangi.

Tujuan dari studi ini adalah mengetahui aplikasi larva black soldier fly (Hermetia illucens) sebagai pakan alami dan pakan buatan (pelet) untuk ikan rainbow kurumoi (Melanotaenia parva).

Metodologi

Studi ini dilaksanakan di Balai Penelitian dan Pengembangan Budidaya Ikan Hias Depok Jawa Barat pada tanggal 14 Januari hingga 14 Februari 2013. Metode yang digunakan dalam kegiatan studi ini adalah metode deskriptif. 
Kultur maggot

Cara pengkulturannya dimulai dengan mencampurkan bungkil kelapa sawit dan air dengan perbandingan 1:2 kemudian diaduk secara merata dan dimasukan kedalam bak fiber dengan diameter $\pm 30 \mathrm{~cm}$, setelah itu bak fiber yang telah terisi PKM dan air yang terfermentasi kemudian dilapisi kawat, diatas kawat diletakan substrat untuk penempelan telur, substrat tersebut terbuat dari daun pisang yang kering yang pada celah-celah daun pisang tersebut lalat betina akan meletakan telurnya setelah melakukan perkawinannya di tanaman Wodelia tribolata.

PKM yang dicampuri air akan menghasilkan bau yang menyengat dan merangsang lalat betina untuk bertelur pada media tersebut. Setelah lalat bertelur sesegara mungkin untuk dipanen dan dipindahkan ke bak penetasan yang berisi fermentasi PKM, fungsi dari bak fiber ini untuk menetaskan telur lalat black soldier menjadi mini maggot maupun big maggot, setelah 2 minggu maggot siap untuk dipanen untuk kegiatan penelitian.

Terdapat 1 kolam beton berbentuk lingkaran digunakan untuk membesarkan maggot menjadi pupa. Dalam 1 kolam beton berbentuk lingkaran diisi PKM yang terfermentasi dengan dicampur air dengan dosis 1:2 yaitu $80 \mathrm{~kg}$ PKM dicampur dengan 160 liter air dan diaduk hingga merata. Kemudian dibiarkan seminggu untuk mengalami proses fermentasi, setelah itu dilakukan penyortiran maggot yang sudah menetas di bak fiber tempat penetasan maggot dengan saringan yang sudah disiapkan terus pisahkan antara mini maggot dengan big maggot untuk mendapatkan maggot yang sama dalam ukuran.

Jika didapatkan big maggot lebih banyak daripada mini maggot dalam proses penyortiran maka yang dimasukan ke kolam beton berbentuk lingkaran berisi PKM terfermentasi adalah big maggot, begitu pula sebaliknya. Pada saat penyortiran mini maggot lebih banyak daripada big maggot sehingga mini maggot yang akan dimasukan kedalam bak beton berisi PKM dan ditunggu beberapa minggu kemudian akan berubah menjadi pupa setelah itu pupa-pupa tersebut dipindahkan ke kotak-kotak restoking untuk berubah menjadi lalat.

Setelah disortir sebagian maggot dijadikan pupa untuk menjadi lalat sebagian lagi dijadikan pelet maggot untuk kegiatan penelitian maupun untuk pakan ikan biasa.
Pemanenan

Pemanenan telur dilakukan 3 kali dalam seminggu yaitu pada hari senin, rabu dan jumat. Pemanenan dilakukan dengan kayu-kayu kecil yang ujungnya lebar, kemudian telur dari substrat diambil dengan kayu tersebut dan diletakan pada wadah kecil. Setelah telur terkumpul kemudian diletakan pada bak fiber untuk ditetaskan. Setelah menetas dan dirasa jumlah larva black soldier fly cukup banyak maka dilakukan penyortiran untuk mendapatkan maggot dengan ukuran dan umur yang hampir sama, penyortiran dilakukan dengan penyaring yang telah disediakan sebelumnya. Kemudian setelah didapat maggot yang sesuai kriteria maka maggot tersebut sebagian akan dimasukan kedalam bak beton berisi PKM untuk dijadikan pupa dan sebagian lagi disimpan didalam lemari es untuk persediaan membuat pelet. Sedangkan pemanenan maggot kesehariannya dilakukan ketika memanen telur kita panen maggot yang menetas di bak hitam dengan cara membuka kawat dan memindahkan substrat keluar terus kita ambil PKM didalam bak tersebut dan dilakukan pengayaan terhadap maggot supaya memisahkan mana maggot yang sesuai dengan bukaan mulut ikan rainbow dan mana yang tidak sesuai dengan bukaan mulut ikan rainbow. Setelah didapatkan maggot yang sesuai kemudian maggot dilakukan penimbangan dengan timbangan digital sesuai dengan jumlah pakan yang diberikan pada ikan rainbow.

\section{Pembuatan pelet}

Teknik Pembuatan pelet dari larva black soldier (maggot) adalah sebagai berikut setelah dilakukan pemanenan dan penyortiran maggot, maggot yang terpilih dimasukkan dalam bak lalu di bersihkan dengan air yang mengalir hingga bersih lalu di masukan kekantong plastik terus dimasukan freezer untuk mematikan maggot selama 24 jam, kemudian dikeringkan dengan alat pemanas selama 12-15 jam dalam temperatur $60^{\circ} \mathrm{C}$ kemudian dilakukan proses penepungan.

Setelah kering ditumbuk ataupun diblender kemudian diayak dan dicetak dengan menggunakan alat pelet dan sesekali diberi air dan di angin-anginkan selanjutnya dimasukan dalam plastik lagi kemudian disimpan dalam lemari es. Dan pelet maggot siap untuk diaplikasikan kepada ikan. Evaluasi tepung maggot secara fisik bewarna hitam pekat, berbau amis dan sedikit berminyak sedangkan pelet magot bewarna hitam pekat, berbau amis, jika ditekan dengan kuat mudah hancur, lama ketahanan dalam air 25 menit, merupakan tipe pelet tenggelam berdiameter $3 \mathrm{~mm}$. 
Pengaplikasian maggot pada ikan

Pakan yang menjadi perlakuan dalam studi ini terdiri dari maggot (Perlakuan A) dan pelet maggot (Perlakuan B). Maggot didapat dari budidaya dan diambil setiap hari, sedangkan pelet maggot diambil di tempat penyimpanan yaitu lemari es. Frekuensi pemberian pakan dilakukan 3 kali sehari, yaitu pada pukul 08.00. 12.00 dan 16.00. Pengaplikasiannya dilakukan dengan memberikan maggot pada akuarium 1, 3, 5 dan memberikan pelet maggot pada akurium 2, 4, 6 . Frekuensi pemberian pakan yang diberikan sebanyak $6 \%$ sehari bobot kering dari biomassa yang didapat dari rumus konversi perhitungan pemberian pakan. Perubahan jumlah pakan diberikan setiap 7 hari sekali.

Rumus pemberian pakannya adalah :

$X=\frac{A}{100} \times B \times \frac{100}{(100-D)}$

Keterangan :

$\mathrm{X}$ : Jumlah pakan yang diberikan (gr)

A : Jumlah pemberian pakan (\%)

B : Jumlah berat ikan (gr)

D : Kadar air pakan (\%)

Kegiatan sampling

Sampling dilakukan setiap 7 hari sekali dengan total sampling 4 kali. Parameter yang diamati adalah pertumbuhan ikan rainbow kurumoi. Parameter pertumbuhan meliputi pertambahan panjang dan pertambahan bobot. Pengamatan dilakukan terhadap semua ikan uji. Ikan uji diukur panjang total, kemudian ditimbang bobot tubuh total.

Untuk pengukuran parameter kimia seperti DO, pH, amonia dan suhu, dilakukan setiap satu minggu sekali. Pengukuran $\mathrm{pH}$ dilakukan dengan menggunakan $\mathrm{pH}$-meter, pengukuran DO menggunakan DO meter yang dilengkapi dengan pengukur suhu.

\section{Hasil dan Pembahasan}

Pemberian maggot dan pelet maggot dapat mencukupi kebutuhan nutrisi ikan rainbow kurumoi selama kegiatan pengaplikasian, hal ini ditandai dengan adanya pertambahan bobot tubuh ikan. Menurut Effendie (1997) dalam Hakim (2011) pertumbuhan dapat didefinisikan sebagai penambahan ukuran panjang atau bobot ikan dalam kurun waktu tertentu yang dapat dipengaruhi pakan yang tersedia, jumlah ikan yang menggunakan pakan, suhu, umur dan ukuran ikan. Pertambahan bobot individu ikan rainbow kurumoi pada tiap perlakuan meningkat seiring berjalannya waktu selama kegiatan studi ini (Gambar 1).

Gambar 1. Memperlihatkan bahwa pertambahan rata-rata bobot individu ikan rainbow kurumoi pada berbagai perlakuan pakan menunjukan nilai yang tidak jauh berbeda. Pada awal pemeliharaan rata-rata bobot individu pada akuarium 1, 3, 5 adalah 9,58 g. Sedangkan awal rata-rata bobot individu pada akuarium 2, 4, 6 adalah 10,02 g. Pada perlakuan A (maggot) didapat rata-rata bobot individu akhir adalah 10,42 dan pada perlakuan B (pelet maggot) didapat rata-rata bobotnya adalah 10,53 g.

Pertambahan bobot ikan rainbow mengalami pertambahan berat yang tidak signifikan. tetapi peningkatan bobot tubuh ikan rainbow selama pengaplikasian maggot

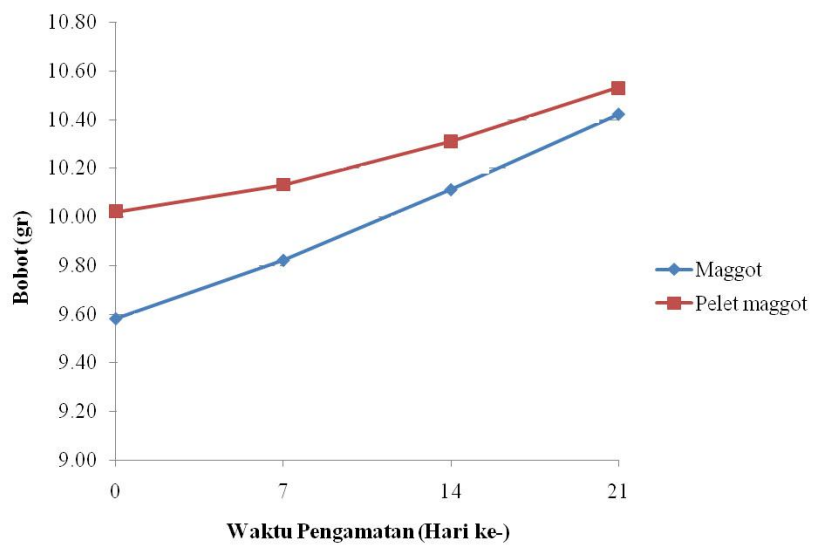

Gambar 1. Pertambahan bobot ikan rainbow kurumoi pada tiap perlakuan 
menunjukan adanya pertumbuhan. Salah satu faktor pertumbuhan adalah pakan yang diberikan. Pakan yang baik adalah pakan yang dapat memenuhi kebutuhan ikan selama hidup. Menurut Amri dan Khairuman (2002) dalam Hakim (2011) pakan ikan yang baik harus memenuhi kriteria-kriteria seperti bahan baku harus tersedia dalam waktu yang lama atau ketersediannya harus kontinyu, bahan baku tidak bersaing dengan bahan makanan manusia, harganya murah, kualitas gizi tinggi, diameter pakan sesuai bukaan mulut ikan, mudah dicerna dan memiliki aroma dan rasa yang disukai (palatabilitas) oleh ikan. Maggot merupakan pakan alami yang bersifat hidup, ukurannya kecil sesuai dengan bukaan mulut ikan rainbow kurumoi dan bergerak lambat sehingga menarik perhatian ikan untuk menangkap dan memangsanya. Kandungan protein maggot tidak mengalami kerusakan karena tidak mengalami proses pemanasan maupun penempungan, sehingga kualitas gizinya masih dapat dipertahankan. Pakan berbahan dasar maggot dapat dimakan dan dimanfaatkan oleh ikan rainbow kurumoi. Ini membuktikan bahwa maggot memiliki aroma dan rasa yang disukai (palatabilitas) oleh ikan rainbow kurumoi. Berbeda dengan maggot, kandungan protein pelet maggot akan berkurang karena telah mengalami proses pemanasan, penggilingan dan penepungan. Walaupun proses tersebut telah mengurangi kandungan protein maggot, tetapi ternyata proses tersebut telah memudahkan ikan rainbow kurumoi untuk memanfaatkan pakan. Hasil rata-rata bobot individu pada setiap perlakuan menunjukan persamaan. Semua itu menjelaskan bahwa kedua bentuk pakan yang diberikan yaitu maggot dan pelet maggot semuanya dapat dimanfaatkan degan baik oleh ikan rainbow kurumoi. Karena sifat dari kedua bentuk pakan tersebut adalah tenggelam, maka sifat pakan yang seperti inilah yang disukai ikan rainbow kurumoi sebagaimana sifat hidup dan kebiasaan ikan rainbow kurumoi yang berda didasar perairan dan pemakan makanan di dasar perairan (bottom feeder). Perlakuan pemanasan, penggilingan, pendinginan maupun penepungan pada bentuk pakan pelet maggot ternyata tidak mempengaruhi daya cerna pakan oleh ikan rainbow kurumoi. Maggot dan pelet maggot sama-sama memberikan pertumbuhan yang baik pada ikan rainbow kurumoi.

Hasil pengamatan pada pengaplikasian maggot dan pelet maggot pada ikan rainbow menghasilkan pertambahan panjang total ikan rainbow kurumoi yang tidak signifikan seperti pada Gambar 2.

Gambar 2. Menunjukan pada awal pemelihaaraan rata-rata panjang tubuh ikan yang akan diberi makan maggot (Perlakuan A) adalah sebesar $5,11 \mathrm{~cm}$, sedangkan pada akhir pemeliharaan rata-rata panjang tubuhnya adalah $5,3 \mathrm{~cm}$. Kemudian yang akan diberi makan pelet maggot (Perlakuan B) rata-rata panjang tubuhnya yaitu $5,26 \mathrm{~cm}$ dan pada akhir pemeliharaan menghasilkan panjang $5,31 \mathrm{~cm}$.

Pertumbuhan ikan salah satunya dapat dilihat dari pertambahan panjang tubuh selama perode pemeliharaan. Wetherley (1972) dalam Hakim (2011) menyatakan bahwa, pertumbuhan merupakan proses bertambahnya ukuran volume, berat atau panjang suatu organisme dapat dilihat dari perubahan panjang atau berat dalam satuan waktu. Pakan merupakan salah satu faktor yang mempengaruhi pertumbuhan panjang.

Menurut Bondari and Shepard (1987) dalam Hakim (2011) kandungan kalsium

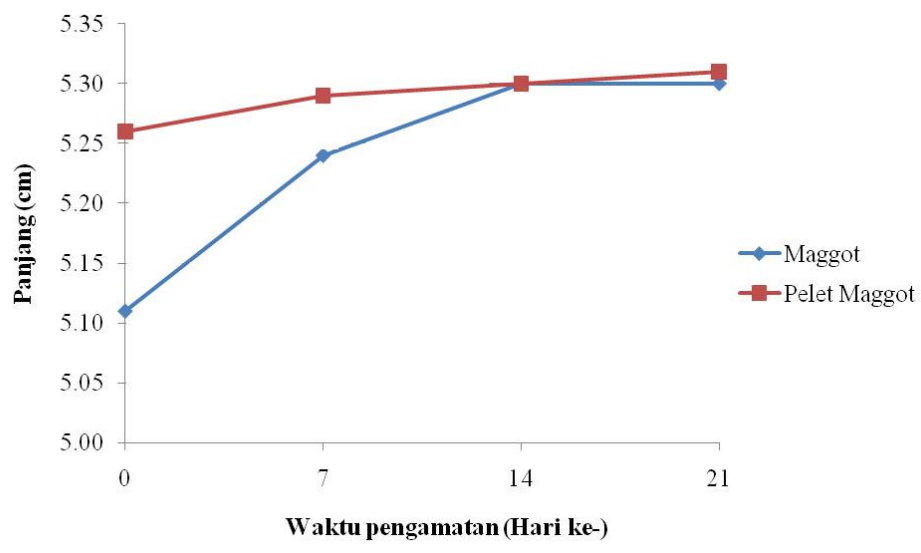

Gambar 2. Panjang total ikan rainbow kurumoi pada tiap perlakuan 
Tabel 1. Kualitas air pada akuarium pemeliharaan ikan rainbow kurumoi tiap perlakuan

\begin{tabular}{|l|l|l|l|l|}
\hline Sample & $\begin{array}{l}\text { Suhu } \\
\left({ }^{\circ} \mathrm{C}\right)\end{array}$ & $\mathrm{pH}$ & $\begin{array}{l}\text { DO } \\
(\mathrm{ppm})\end{array}$ & $\begin{array}{l}\text { Amonia } \\
(\mathrm{ppm})\end{array}$ \\
\hline Tandon Air & 26,77 & 6,07 & 5,07 & 0,36 \\
Perlakuan A & 26,07 & 6,73 & 7,68 & 0,00 \\
Perlakuan B & 26,30 & 6,69 & 6,84 & 0,01 \\
\hline
\end{tabular}

Keterangan : Perlakuan $\mathrm{A}=$ Pakan maggot

Perlakuan $\mathrm{B}=$ Pakan pelet maggot

maggot sebesar 4,8\%-5,1\% dan phosphor sebesar $0,60 \%-0,63 \%$ dalam bentuk kering, sehingga pertambahan panjang ikan rainbow kurumoi yang dihasilkan oleh kedua bentuk pakan tersebut tidak berbeda jauh. Kandungan kalsium yang sama tersebut karena pakan yang diberikan hanya berasal dari satu jenis pakan saja yaitu maggot.

Pengelolaan kualitas air menggunakan sistem filter atau dikenal resirkulasi alternatif yang untuk air tetap optimum. Resirkulasi adalah sistem yang menggunakan air secara terus menerus dengan cara diputar dialirkan ke wadah berupa filter untuk dibersihkan kemudian dialirkan untuk digunakan kembali. Sistem ini mempunyai keuntungan dalam menjaga kualitas air dan menghemat penggunaan air. Hasil dari pengukuran kualitas air pada akuarium didapat seperti pada Tabel 1 .

Nilai parameter kualitas air baik pada tandon air, akuarium pemeliharaan ikan rainbow kurumoi dengan pakan maggot (Perlakuan A), dan akuarium pemeliharaan ikan rainbow kurumoi dengan pelet maggot (Perlakuan B) masih sangat baik bagi pemeliharan ikan rainbow kurumoi.

\section{Kesimpulan}

Maggot dan pelet maggot dapat mencukupi kebutuhan nutrisi ikan rainbow kurumoi hal ini ditandai dengan adanya pertambahan bobot dan pertambahan panjang ikan rainbow yang dibudidayakan.

\section{Daftar Pustaka}

Fahmi, M.R., Hem, S., dan Subamia, I.W. 2007. Potensi Maggot Sebagai Sumber Protein Alternatif. Prosiding Nasional Perikanan II. UGM. $5 \mathrm{hlm}$.

Fahmi, M.R., Hem, S., dan Subamia, I.W. Potensi Maggot Sebagai Salah Satu Sumber Protein Pakan Ikan.
Seminar Nasional Hari Pangan Sedunia XXVII Dukungan teknologi Untuk Meningkatkan Produk Pangan Hewani Dalam Rangka Pemenuhan Gizi Masyarakat. Loka Riset Budidaya Ikan Hias Air Tawar Depok. 6 hal.

Hadadi, A., Herry, Setyorini, A. Surahman dan E. Ridwan 2007. Pemanfaatan limbah sawit untuk bahan pakan ikan. Jurnal Budidaya Air Tawar Volume 4 No. 1 Mei 2007 (11-18)

Hakim, L.L. 2011. Pengaruh pemberian larva maggot, pasta maggot dan pelet maggot terhadap pertumbuhan benih ikan botia (Chromobotia macracanthus) di Balai Penelitian dan Pengembangan Budidaya Ikan Hias Depok. Skripsi. Jurusan budidaya perairan. Universitas Padjajaran Banten. Banten 51 hal.

Kadarini, T., Prihandani, E. 2011. Dukungan pendederan ikan rainbow kurumoi (Melanotaenia parva) terhadap konservasi sumber daya ikan di papua. Prosiding Forum Nasional Pemacuan Sumber Daya Ikan III. 11 hal.

Kordi, G. 2009. Budi Daya Perairan Jilid 2. PT Citra Aditya Bakti. Bandung.

Sudarto \& B. Nur. 2008. Biodiversitas ikan pelangi (Rainbowfish) asal Indonesia Bagian Timur dalam Supriyadi, H., A.Hanafi, A.H.Kristanto, Chumaidi, A. Mustafa, Imron \& I. Insan. Teknologi Perikanan Budidaya. Pusat Riset Perikanan Budidaya. 455-462 pp. 